LUKASZ KOŻUCHOWSKI

Uniwersytet Warszawski, Kolegium Międzyobszarowych Indywidualnych Studiów Humanistycznych i Społecznych

„MIOTELKI” Z MELODRAMY „CHLOP MILIONOWY” JAKO WARSZAWSKI FENOMEN SPOLECZNO-KULTUROWY

\title{
1. Wstęp
}

Celem niniejszej pracy jest opisanie zjawiska społecznego, jakim była popularność „Miotełek” w Warszawie przełomu lat 20. i 30. XIX wieku. Tym mianem określano wówczas piosenki, które pierwotnie wykonywał aktor grający rolę Fortunata w napisanej przez austriackiego dramaturga Ferdinanda Raimunda melodramie Chtop Milionowy (Krzysztoforska-Weisswasser 2007: 176; Raimund 1829: 94-97). Było to najpopularniejsze przedstawienie teatralne tamtych czasów. Rekordami frekwencji zdecydowanie wyróżniało się na tle innych sztuk wystawianych w Teatrze Narodowym (Szwankowski 1973: 30-31). Tytułowy bohater dramatu, noszący znaczące imię Fortunat, wskutek własnych przywar traci majątek, którym został cudownie obdarowany przez siły wyższe. Strącony z piedestału na margines społeczny, trudzi się sprzedażą miotełek. Aby umilić sobie pracę, śpiewa piosenki komentujące rzeczywistość społeczną, jak najbardziej przystającą do realiów ówczesnej Warszawy. Nazwa tychże śpiewek została zaczerpnięta z charakterystycznych ostatnich słów, którymi Fortunat zazwyczaj zachęca przechodniów do kupna swoich towarów: „Miotły! Miotełki!". Piosenki te, wykonywane podczas przedstawienia najpierw przez Jana Nowakowskiego (Raszewski i in. 1973: 485), a później Józefa Niwińskiego (Raszewski i in. 1973: 480), cieszyły się wielkim powodzeniem. Szybko zagościły nie tylko na ustach wielu warszawiaków, którzy chętnie je śpiewali i nucili, ale też w prasie czy na salonach. Ramy czasowe zagadnienia omawianego w niniejszej pracy wyznaczają dwie daty: warszawska premiera Chłopa Milionowego na scenie Teatru Narodowego dnia 26 XI 1829 r. oraz ostatnia odnotowana wzmianka prasowa o „Miotełkach” - 10 XII 1830 r.

Cel niniejszego tekstu stanowi zwrócenie uwagi na tenże fenomen oraz próba, w miarę możliwości dawanych przez ocalałe do dziś źródła historyczne, opisania go. Przedstawione zostaną różnorodne aspekty historii „Miotełek”. Podjęta zostanie próba odpowiedzi na pytania: jak wyglądały reakcje opinii publicznej na „Miotełki”? Jak rozwijała się ich popularność? Co można powiedzieć o bazie społecznej miłośników „Miotełek”? Co „Miotełki” mogą nam powiedzieć o mentalności i przeżyciach ówczesnej Warszawy?

Dla uzyskania wglądu w wyżej wymienione zagadnienia zostana użyte różnorodne źródła historyczne, przede wszystkim prasa warszawska z przełomu lat 20. I 30 XIX wieku: „Gazeta Korrespondenta Warszawskiego y Zagranicznego”, „Gazeta Polska”, „Kurjer Polski”, „Kurjer Warszawski” oraz „Powszechny Dziennik Krajowy”1. Dzięki nim jest znana ogólna skala popularności zarówno samego Chłopa Milionowego, jak i „Miotełek”. Czasopisma te często publikowały również piosenki, nieobecne w żadnych innych przekazach. Wartościowy będzie też oczywiście sam tekst

1 W przypisach będę używał skrótów od nazw tychże czasopism: „Gazeta Korrespondenta Warszawskiego y Zagranicznego” - GK, „Gazeta Polska” - GP, „Kurjer Polski” - KP, „Kurjer Warszawski” KW, „Powszechny Dziennik Krajowy”- PDK. 
melodramy oraz publikowane jako samodzielne wydawnictwa niektóre „Miotełki”, które obecnie znajdują się w zbiorach Muzeum Teatralnego w Warszawie ${ }^{2}$.

\section{Pierwsze reakcje}

\section{1. „Miotełki” w pierwszych recenzjach prasowych Chłopa Milionowego}

Prasa, choć prezentowała recenzje spektakli Chłopa Milionowego, nie zawsze wprost zwracała uwagę na wykonywane podczas nich „Miotełki”. Jako pierwsza, bo już w dzień po warszawskiej premierze spektaklu, opinię na jego temat przedstawiła „Gazeta Korrespondenta Warszawskiego y Zagranicznego”, która doceniając i komplementując ogół kreacji aktorskiej Nowakowskiego - odtwórcy roli śpiewającego „Miotełki” Fortunata - zgłaszała jednak pewne zastrzeżenia:

Ośmielamy się tylko małą uczynić P. Nowakowskiemu uwagę. Występując w akcie 3, jako nędzny, obdarty, zgłodniały i mioteł sprzedażą trudniący się starzec, P. Nowakowski przy całym nieszczęściu nadał swej roli cechę pewnego rodzaju wesołości. Pomimo wszelkich klęsk które go obarczyły, przecież na jego ustach częsty maluje się uśmiech i zdaje się tak jak gdyby kontent był z swego losu. Inaczej sobie (o ile nam się zdaje) zamierzył autor (GK 1829, nr 274: 3437—3438).

Również w krytycznym tonie wypowiedział się autor recenzji nadesłanej do „Gazety Polskiej”; co ciekawe - widząc w grze Nowakowskiego cechy inne niż omówione w „Gazecie Korrespondenta”: „Śpiewka z miotłami była (...) nienaturalna. Pan Nowakowski oddał ją głosem jękliwym i nieprzyjemnym” (GP 1829, nr 323: 1390).

Niemniej jednak inne recenzje opublikowane w dniach pierwszych spektakli wyraźnie, acz bez wyszczególnień, komplementowały zaprezentowany na scenie kunszt aktora. Nie czynią przy tym wyjątków dla żadnego z elementów jego gry, w tym końcowych śpiewek. Przykładem takiego czasopisma był „Powszechny Dziennik Krajowy", w którym napisano:

Będąc w Wiedniu, miałem sposobność widzenia sławnego Raimunda, występującego w roli chłopa milionowego. Śmiało wyznać mogę, że nasz ziomek P. Nowakowski nic mu nie ustępuje; szczególnie gra jego, gdy starość pozbawia go sił młodości, nie zostawia nic do życzenia, niepodobna lepiej jest oddać nagłego przejścia z stanu czerstwości, w nagłą zgrzybiałość (PDK 1829, nr 308: 1410).

W podobny sposób swoje votum separatum zgłosił także nowopowstały „Kurjer Polski” (KP 1829, nr 1: 4). Co więcej, jego redaktor, Maurycy Mochnacki, poczuł się w obowiązku wystąpić przeciwko deprecjonowaniu Nowakowskiego oraz Chłopa Milionowego. „Gazeta Polska” została ostrymi słowami zaatakowana już w kilka dni po opublikowaniu wspomnianej wyżej nieprzychylnej recenzji:

Zdania Gazety Polskiej wobec Chłopa milionowego zasługują na uwagę! (...) utrzymuje artykuł w Gazecie Polskiej, że P. Nowakowski nienaturalnie wykonywa swoją rolę, że przesadza i że śpiewka z miotełkami jest także nienaturalna. Nam się zdaje że podobne artykuły raczej w Gazecie Polskiej sa nienaturalne, niezgodne $\mathrm{z}$ duchem poprzedzających w tym piśmie artykułów o tworach sztuki i grze P. Nowakowskiego. Kto tylko widział Fortunata przyzna, że gra jego, a osobliwie śpiewki z miotełkami są tryumfem sztuki (KP 1829, nr 5: 21).

Na równie zaciekłą odpowiedź „Gazety Polskiej” nie trzeba było długo czekać pojawiła się już następnego dnia:

\footnotetext{
${ }^{2} \mathrm{~W}$ przypisach dla będę zamiast nazwy „Muzeum Teatralne w Warszawie” używał skrótu: MT.
} 
Wczorajszy Kurjer Polski powstaje przeciwko G. P. [tj. „Gazecie Polskiej” - przyp. aut.] za to, że zdanie umieszczone w jej Nrze 323 o grze pana Nowakowskiego, nie zgadza się z jego zdaniem. Utrzymuje on, ze gdy poprzednio znajdowały się w Gazecie Polskiej pochwały talentu pana Nowakowskiego, dzisiaj nie godzi się umieszczać artykułów, które w grze tego artysty, zboczenie lub uchybienie jakie postrzegają; słowem, K. P. [tj. „Kurjer Polski” - przyp. aut.] chce mieć grę P. Nowakowskiego wyższą nad wszelkie zdanie; nietykalną. (...) Ale Kur. Polskiemu nie szło ani o P. Nowakowskiego, ani o grę jego; chciał on jedynie dotknąć G. P., szukał więc pretekstu (GP 1829, nr 327: 1408).

W podobnym czasie przychylna wobec „Miotełek” wypowiedź ukazała się w „Gazecie Korrespondenta Warszawskiego y Zagranicznego" - wskazywała ona nie tylko na popularność „Miotełek” wśród publiczności, ale też prezentowała kilka ich tekstów (GK 1829, nr 280: 3483-3484). Zarazem jednak pojawiły się krytyka z innej strony - na łamach tego czasopisma ujawnił się głos widzący w śpiewkach nieprzyzwoitość i upadek obyczajów:

Cóż powiedzieć gdy niektórzy thumacze sztuk teatralnych, w swoich przekładach, rażą smak i ucho dobrze wychowanej publiczności. Ostateczne w tej mierze przekonanie mieliśmy w Chłopie milionowym, tak w prozie jak w wierszu. Na dowód tego nie mając jak WPana gazetę przed oczyma, przytoczę tylko tę parę wierszy (z ulubionego kupletu) o miotłach. Cóż to za Pani ta, / Co na tbie fiołki ma? Wyraz ten zamieszczony w ostatnim wierszu, grzeszy przeciwko przyzwoitości. (GK 1829, nr 281: 3491).

Niemniej jednak ataki na Nowakowskiego i jego piosenki już po upływie niecałych dwóch tygodni od pierwszego wystawienia spektaklu zdawały się wyciszać. „Gazeta Polska”, tak ostro zaatakowana przez „Kurjer Polski” za zaprezentowane na swoich łamach zastrzeżenia, opublikowała wkrótce potem obszerną recenzję przychylną Chłopu Milionowemu (GP 1829, nr 329: 1416-1417), a następnego dnia zwięzły artykulik, w którym wprost stwierdzono, jakby na przekór jednemu z cytowanych już tekstów: „Co się tycze pana Nowakowskiego (...) w wielu względach naszemu rodakowi przyznaję pierwszeństwo, gdyż Szuster [tj. aktor grający Fortunata w teatrze wiedeńskim - przyp. aut.] najniższą klasę starał się bawić; przeciwnie pana Nowakowskiego wszyscy lubią" (GP 1829, nr 330: 1420)

Owa tendencja ocieplania opinii wyrażanych o spektaklu wyraźnie wskazuje, że chociaż z początku „Miotełkom” zarzucano czasem w prasie niestosowność, obiekcje te zostały dość szybko przełamane. W późniejszym czasie głosy krytyczne pojawiały się sporadycznie (np. GK 1829, nr 299: 3643) - poza tym wyjątkiem o śpiewkach Nowakowskiego pisano w prasie już albo dobrze, albo wcale.

\subsection{Zdanie publiczności}

Zdecydowanie mniej zróżnicowane i nie przejawiające oznak nieprzychylności wydaje się już od samego początku zdanie szerszej publiki. Wypełniała ona tłumnie gmach teatru nie tylko na premierze Chłopa Milionowego, ale i podczas wielu późniejszych przedstawień (Szwankowski 1973: 32). Niewątpliwie świadczy to o upodobaniu publiczności różnych warstw społecznych do tejże melodramy, w czym „Miotełki” z pewnością miały swój udział. Prasa wspominała także kilkakrotnie, że Nowakowski stał się ulubieńcem publiki, a jego piosenek wyczekiwano. Po spektaklach był on w dowód aprobaty przywoływany (KW 1829, nr 322: 1439; nr 329: 1475), przy czym często wprost żądano powtórzenia śpiewek, któremu to żądaniu wykonawca nie omieszkiwał sprostać (KW 1829 nr 319: 1427; nr 327: 1467; nr 334: 1503). Bez 
wątpienia satysfakcjonowało to i samego aktora, który serdecznie dziękował publiczności - oczywiście także w formie „Miotełki”:

Ulubiona śpiewka Miotły Miotełki zawsze na powszechne żądanie jest powtarzaną, a JP. Nowakowski przywoływany. Wczoraj [tj. 13 XII 1829 r. - przyp. aut.] ten Artysta składając dzięki za łaskawe względy Publiczności, zakończył śpiewkę nową następującą strofą. I dla mnie ma też świat / Wśród cierni piękny kwiat, / Ach! Względy wasze to / Tym drogim kwiatem sa, / Jak miło dla nich żyć / I sługą waszym być! / Gdybym wam zimno grał / Sam sobie wnet bym dał / Miotły! Miotełki! (KW 1829, nr 334: 1503).

I po spektaklach najwyraźniej mile wspominano te piosenki, skoro „Gazeta Korrespondenta Warszawskiego y Zagranicznego", z początku prezentująca niechętne wobec nich notki, opublikowała już w kilka dni po premierze następującą informację: ,[Na przedstawieniach Chłopa Milionowego] publiczność zawsze zgromadza się licznie i często przyklaskuje ulubionym sobie kupletom śpiewanym przez Chłopa (...) Spiewkę tę, na kilkakrotne listowne wezwania umieszczamy" (GK 1829, nr 280: 3483). Po tychże słowach następuje pełny tekst aż czterech „Miotełek”.

Warto oczywiście nadmienić, że wskazane powyżej relacje prasowe przedstawiają zapewne tylko część przejawów tego, jak bardzo śpiewki Nowakowskiego przypadły do gustu wielu mieszkańców Warszawy już w pierwszych tygodniach po premierze Chłopa Milionowego. Fenomen tego szczególnego upodobania w ciągu następnych miesięcy nie osłabł; wręcz przeciwnie - rozwijał się i stał się samodzielny w stosunku do tekstu przedstawienia i gry scenicznej aktorów.

\section{3. „Miotelek" życie własne 3.1. Projekt wydawniczy}

Sukces sceniczny był tak wielki, że powzięto pomysł wyeksploatowania go także w pozateatralnych formach. Zauważono, iż „Miotełki” mają pewien potencjał komercyjny. Dlatego też $\mathrm{w}$ porozumieniu $\mathrm{z}$ Nowakowskim podjęto inicjatywę ogłoszenia drukiem kilku jego tekstów. Były one reklamowane, co ważne, jako podobne do tych wykonywanych na scenie i mające tego samego autora. Słowa piosenek opatrywano rycinami, zachwalanymi jako wiernie oddające gesty i fizjonomię wykonawcy roli Fortunata. Już na początku grudnia 1829 r. ukazały się w kilku tytułach prasowych ogłoszenia, wstępnie informujące o zaistniałych planach (KP 1829, nr 7: 29; PDK 1829, nr 317: 1449). Wkrótce po opublikowaniu tychże informacji z inicjatywy Józefa Damsego, tłumacza Chłopa Milionowego na język polski, wydrukowano i sprzedawano tekst piosenek wykonywanych podczas przedstawienia podpisując je nie nazwiskiem Nowakowskiego, lecz Damsego właśnie (KW 1829, nr 337: 1520). Jego inicjatywa, która bez wątpienia musiała spotkać się z pozytywną recepcją licznych nabywców, najwyraźniej zachęciła Nowakowskiego i jego wydawców do podjęcia dalszych kroków, gdyż jeszcze w tym samym miesiącu podano do wiadomości kolejne, precyzyjne już ogłoszenia, informujące o możliwości prenumeraty oraz kupna pojedynczych egzemplarzy tekstów śpiewek. Często te drukowane „Miotełki” bywały już wcześniej wykonywane na scenie - być może w charakterze reklamy. W tych ogłoszeniach nowe wydawnictwa były zachwalane nie tylko jako zawierające kolejne przyjemne piosenki oraz miłe dla oka litografie, ale też jako realna możliwość materialnego odwdzięczenia się Nowakowskiemu za jego grę i inwencję - zysk ze sprzedaży „Miotełek” miał zasilać jego prywatny budżet. W kolportażu tych wydawnictw wielu musiało od razu zauważyć żyłę złota, gdyż prenumeratę można było zamówić w wielu miejscach - w kantorach wszystkich ówczesnych warszawskich 
dzienników, kilku sklepach, księgarniach czy w kasie teatralnej (GP 1829, nr 342: 1472; KP 1829, nr 21: 103; KW 1829, nr 342: 1546; PDK 1829, nr 330: 1500).

Przedsięwzięcie rzeczywiście się powiodło - wiele wskazuje na to, że nowe „Miotełki” cieszyły się dużą popularnością. Po wydaniu dla prenumeratorów czwartej z nich, umożliwiono także nabywanie pojedynczych egzemplarzy, co może sugerować, iż popyt wzrastał w czasie i wydawanie tylko w formie prenumeraty nie zaspokajało zapotrzebowania. Cena pojedynczych tekstów była wyższa niż przy zainicjowanej przez Damsego sprzedaży „Miotełek” śpiewanych na pierwszych spektaklach - wówczas opłatą żądaną za kilka piosenek (w ogłoszeniu nie widnieje dokładna liczba) było 15 groszy (KW 1829, nr 337: 1520), zaś przy późniejszej akcji wydawniczej „Miotełek” Nowakowskiego były to już 2 złote 15 groszy za jedną piosenkę (KP 1830, nr 79: 404), czyli nawet więcej, niż wynosiła cena egzemplarza samego pełnego tekstu Chłopa Milionowego (KW 1829, nr 337: 1520). Trudno ów fakt tłumaczyć jedynie tym, że nowe „Miotełki” opatrywano rycinami, których wykonanie oczywiście oznaczało nowe koszty. Dodano także możliwość zgłaszania woli prenumerowania poza Warszawą w lokalnych urzędach pocztowych (KP 1830, nr 79: 404).

Finalnie $\mathrm{w}$ ten sposób opublikowano dziesięć utworów. Z nieznanych przyczyn w realizacji tegoż planu nastąpiło opóźnienie: wydanie ostatniej, dziesiątej „Miotełki” zapowiadano na luty 1830 r. (GP 1829, nr 342: 1472; PDK 1829 nr 330: 1500), podczas gdy ostatni możliwy do precyzyjnego datowania tekst (dziewiąty) ukazał się 18 kwietnia 1830 r. (KP 1830, nr 121: 615).

\subsection{Bitwa prasowa o autorstwo}

Przy tak intratnym interesie rychło pojawił się spór o to, kto ma prawo do partycypowania w nim. Toczył się on publicznie - na łamach prasy - a w swym charakterze, zaciekłości oraz komercyjnym podtekście wyraźnie przypominał dzisiejsze spory o prawa autorskie. W dwa dni po ogłoszeniu konkretów dotyczących projektu wydawania „Miotełek” Józef Damse, tłumacz Chłopa Milionowego, opublikował w „Kurjerze Warszawskim” następującą informację:

Mam honor donieść Szanownej Publiczności, iż śpiewki Miotlarza, szczególnie pierwsze cztery, są moje, a tym bardziej pomysł Miotełek w miejsce niemieckiego Aszennman (Popielarza) do mnie należy, następnie zaś piosenki są dziełem JP. Nowakowskiego, mojego kolegi. Nie śmiałbym, drukując egzemplarz, umieścić mego nazwiska na czele, gdyby przeciwnie było (KW 1829, nr 343: 1547).

Nietrudno w tym manifeście dostrzec chęć Damsego do przyłączenia się do (albo wręcz przywłaszczenia sobie) powstającego właśnie dochodowego przedsięwzięcia, jakim jawiło się publikowanie „Miotełek”. Wobec takiego zachowania wydawcy tekstów Nowakowskiego przystąpili do obrony, trzy dni później umieszczając w „Powszechnym Dzienniku Krajowym” swoje stanowisko:

W ogłoszeniu na Miotełki Nowakowskiego wspomnieliśmy, że śpiewki Miotlarza, ten artysta sam sobie pisał. Przeciwko tym wyrazom zdaje się JP. Damse protestować doniesieniem publiczności, że te śpiewki są jego. Udaliśmy się przeto po objaśnienie do JP. Nowakowskiego, który nam oświadczył co następuje: JP Damse napisał w rzeczy samej cztery śpiewki dla Miotlarza, lecz z tych trzy nie były nigdy śpiewane i nie są drukowane; jedną tylko JP. Damsego śpiewał Miotlarz, a prócz niej jedenaście swoich, i tych nam na wezwanie nasze udzielił (...) Gdy zaś JP. Damse prosił JP. Nowakowskiego o pozwolenie drukowania jego śpiewek na swoją korzyść, na to więc tenże zezwolił. 
Do powyższego objaśnienia dodajemy nasze; odebraliśmy tylko jedenaście śpiewek i stosownie do nich ogłosiliśmy prenumeratę na jedenaście karykatur, to jest dziesięć na osobnych kartach a jedną na okładce. W tych jedenastu śpiewkach nie masz tej, którą JP. Damse napisał; łatwo ją $\mathrm{z}$ resztą poznać i w drukowanym egzemplarzu, gdyż tym różni się od innych: że ma w końcu rym żeński, nie zgodny z rytmem melodii. -W takim stanie rzeczy trudno nam pojąć celu doniesienia JP Damsego: nie tknęliśmy się albowiem niczym autorstwa jego strofki; przeciwnie, on drukował na swoją korzyść śpiewki pisane przez IP. Nowakowskiego, a nie wymienił ich autora: któż więc w tym razie przybrał się w cudze piórka? (...)

- (Wydawcy słusznie mówią, że trudno pojąć cel ogłoszenia JP. Damsego, tym bardziej, gdy Kuryer Polski doniósł, że już ustało stronnictwo zakulisowe przeciwko JP. Nowakowskiemu) (PDK 1829, nr 334: 1516).

Podobnej treści ogłoszenie ukazało się później także w „Kurjerze Warszawskim” (KW 1829, nr 346: 1566) oraz „Gazecie Polskiej” (GP 1829, nr 348: 1497-1498).

Damse wobec takiej odpowiedzi Nowakowskiego i jego wydawców musiał ustąpić pola. Jednak wypowiedział się jeszcze na łamach prasy, gdzie zdawał się z jednej strony utrzymywać swoje stanowisko, ale zarazem usiłował załagodzić konflikt, w którym nie miał szans zwyciężyć:

Prawdziwie, biorąc miarę $\mathrm{z}$ połajania jakim mnie obdarzyć raczyli Wydawcy miotełek Nowakowskiego, sądziłby kto, że ja chcę być przeszkodą w zamierzonym ich celu, a niech mnie Bóg zachowa! I owszem, z całego serca życzę im najlepszych skutków z prenumeraty, i dla tego tylko umieściłem w pismach publicznych doniesienie, iż kilka strof o miotełkach jest moich, ponieważ wydawcy miotełek Nowakowskiego w prospekcie przyznali wszystkie temuż P. Nowakowskiemu, a tu się ma rzecz przeciwnie, pomimo że P. Nowakowski wydawców zapewnił, jak oni twierdzą, a w czym zajść musiało nieporozumienie (...) Zresztą tak Chłop Milionowy jak i Miotełki tak mało wzbogaciły literaturę, że nie warto wojować o nie piórami (...) jak to najlepiej osądzi Szanowna Publiczność, której względom polecając się, zostaję najuniżeńszym sługą.

Bezpośrednio po powyższym tekście następuje notka redakcji „Powszechnego Dziennika Krajowego", która tak podsumowała całą sytuację:

Pokazuje się zatem, iż wszystko, co Wydawcy Miotełek Nowakowskiego przytoczyli, jest prawdą; po cóż więc JP. Damse czynił reklamacje o śpiewki, których nie śpiewano, i których nawet sam, drukując swój przekład Chłopa milionowego, nie wydrukował? (...) Spodziewamy się, że ten autor polecający się względom szanownej publiczności, będzie na przyszłość ostrożniejszy (PDK 1829, nr 337: 1528).

Skoro wyjaśnieniom stało się zadość, a Damse musiał upokorzony wycofywać się ze swoich roszczeń, zakończyła się emocjonalna dyskusja na łamach prasy. Bynajmniej nie zaszkodziła ona popularności „Miotełek”, których sława zataczała coraz szersze kręgi.

\subsection{Miotelki na salonach}

Wydanie „Miotełek” drukiem niewątpliwie przyczyniło się do wzrostu ich popularności. Wiadomym jest bowiem, że podczas zabaw towarzyskich wyższych sfer w trakcie zimy 1829/1830 r. pojawiały się one jako miłe urozmaicenie.

Fryderyk Chopin, wówczas młody i dobrze zapowiadający się pianista, podczas jednego ze swoich koncertów uraczył publikę własnymi wariacjami na temat melodii śpiewek (KW 1829, nr 341: 1540). Co ciekawe, zrobił to, chociaż o samym Chłopie Milionowym miał niskie mniemanie (Miziołek 2015: 394). Sama warstwa muzyczna piosenek musiała więc być na tyle chwytliwa, że urzekła kompozytora. 
Także podczas loterii noworocznych zabawiano się, nie tylko wykonując śpiewki napisane przez Nowakowskiego, ale też przedstawiając i te wymyślone przez siebie:

Wspomnieliśmy już o rozmaitych loteriach, którymi się zabawiano przy wstępie do nowego roku. $\mathrm{W}$ jednym znakomitym domu warunkiem było dopisać do fantu przyniesionego wiersz nieco płaski i zabawny. (...) Tymczasem kładziemy tu niektóre z tych wierszy: (...) Przy miotełkach napełnionych cukierkami, czytano wiersz taki: Przednie lekarstwo mam, / Dla wszystkich panien dam, / Na nerwy, mdłości, płacz, / Tylko spróbować racz, / Lecz jeśli to jest grzech, / Że je obracam w śmiech, / Wybaczcie mi ten błąd, / I rzućcie razem w kąt. / Miotły Miotełki (KP 1830, nr 38: 195).

Również podczas kostiumowego balu dziecięcego u Józefa Krasińskiego, hrabiego i wysokiego urzędnika państwowego, dla urozmaicenia wspólnie spędzanego czasu przybyli dwaj miotlarze (KW 1830, nr 50: 249). Także i w trakcie jednej z maskarad dla wyższych sfer pojawić się miał rozdający teksty śpiewek miotlarz (KW 1830, nr 24: 109).

Jak wskazują powyższe przykłady, „Miotełki” nie dość, że nie zostały uznane, jak postulowali niektórzy wcześniej w prasie, za coś niskiego i plebejskiego, niegodnego kulturalnego towarzystwa, ale wręcz stały się czymś w dobrym guście, odpowiednim także do umilenia zabaw i dorosłym, i dzieciom.

\subsection{Miotelki na ulicach}

Próbując określić stopień popularności „Miotełek” wśród warstw niższych, oczywiście ma się do dyspozycji o wiele mniej źródeł niż w przypadku elit, których życie chętnie relacjonowała prasa. Można próbować wnioskowania pośrednio, że utrzymująca się wysoka frekwencja na spektaklach (Szwankowski 1973: 31), która musiała być wynikiem zaangażowania się nie tylko bogatszych, ale też (czy wręcz przede wszystkim) uboższych widzów, miała swoje źródło zapewne i w powszechnej chęci ujrzenia Nowakowskiego w roli Fortunata. Prócz tego warto odnotować, że niektóre $\mathrm{z}$ opublikowanych $\mathrm{w}$ prasie tekstów, które negatywnie wyrażały się o niemalże monopolu Chłopa Milionowego w repertuarze Teatru Narodowego, w wyraźny sposób obarczały winą za ów stan klasy niższe. Chłopa uznawano w nich za twór płytki, wielce cieszący niewyrafinowane masy, lecz nużący po pewnym czasie elity, czy wręcz od samego początku nielicujący z ich wysublimowanym gustem (KP $1830 \mathrm{nr} 31: 153$ ). Niemniej jednak do naszych czasów przetrwała jedna doprawdy intrygująca i dość precyzyjna relacja prasowa:

Zwykle po każdej operze nowej, powtarza z niej młodzież najprzystępniejsze arie; niekiedy nawet na ulicach słyszeć można powtarzane piosnki, które się najwięcej na teatrze podobały. Nie inaczej ma się rzecz z piosenkami Miotlarza z Chłopa milionowego; powtarza każdy i każda, jeśli nie słowa, to przynajmniej ich melodię. Ale dopiero pierwszy raz zdarzyło nam się słyszeć z tej sztuki piosenki polskie, śpiewane przez Izraelitów. Melodia śpiewek Miotlarza jest tak przyjemna, a same śpiewki tak trafne do wad powszechniej w stolicy znanych, są zastosowane, iż nawet na Franciszkańskiej ulicy rozlega się ich odgłos (KP 1829, nr 29: 146).

Popularność „Miotełek” dokonała więc rzeczy niepospolitej w swoich czasach: stała się tekstem kultury wspólnym wielu mieszkańcom miasta niezależnie od narodowości i religii, które na co dzień częstokroć powodowały podziały. Nie jest jednak możliwe precyzyjniejsze określenie skali oraz charakteru tegoż zjawiska dostępne dziś źródła są niestety nazbyt małomówne w tej kwestii. 


\subsection{Twórczość fanów i krytyków}

Kolejnym argumentem przemawiającym za wielką popularnością „Miotełek” jest fakt, że oprócz „kanonicznych” piosenek, których autorami byli aktorzy Teatru Narodowego, powstało też wiele podobnych utworów wymyślonych przez entuzjastów ich twórczości. Świadczy to o tym, że nie tylko wiele osób poznało „Miotełki”, ale też część z nich głęboko je sobie przyswoiło (Kulesza-Gulczyńska 2014: 166).

Własna twórczość powstawała zarówno spontanicznie - z przypływu weny twórczej inspirowanej oryginalnymi piosenkami (KP 1830, nr 129: 660 -661), ale także na potrzeby wystawienia Chłopa Milionowego w Lublinie (KP $1830 \mathrm{nr}$ 140: 716-717) czy też jego parodii zaprezentowanej w warszawskim Teatrze Rozmaitości (KW 1830, nr 66: 329-330). Ich forma oraz tematyka była zbliżona do pierwotnych „Miotełek”. Liczba powstałych w ten sposób śpiewek była znaczna - do dziś zachowało się kilkanaście zwrotek tego typu utworów.

W formie „Miotełki” nie tylko układano własne wierszyki dla przyjemności tudzież celów komercyjnych, ale i pisano bardziej teksty o bardziej pragmatycznym charakterze. Jednym z rodzajów tego typu twórczości było... krytykowanie mnożenia się nowych „Miotełek”. Wskazywano na to, że w znacznej mierze ustępują swoim pierwowzorom:

Mnożąca się liczba naśladowców pisarza dowcipnych Miotełek, słuszną nabawiła trwogą okolicę naszą (...). Przejęty duchem ogólnego dobra, zanoszę prośbę do Sz. Redakcji aby w swym piśmie umieścić raczyła następującą dla tych panów przestrogę:

Gdy cię napada szał / Byś z rymów chwałę miał, / Pstrych drugim przypiął łat / I brednie puszczał w świat / Braciszku pióro rzuć, / Pod nosem sobie nuć / A wziąwszy ostry nóż / Brzozowe lepiej struż / Miotły! Miotełki! (KP 1830, nr 153: 777).

Miotełki zostały zaangażowane także w bieżące spory dotyczące kultury elitarnej. W ich formie została wyrażona negatywna opinia na temat twórczości romantyków. „Miotełki” krytykowane niegdyś jako schlebiające niewyrafinowanym gustom, zostały przez to włączone do sfery polemik dotyczących „,wielkiej” literatury:

Jeden ze starowierców rymotwórstwa [tj. klasycystów - przyp. aut.] napisał kilka zwrotek na tak zwanych romantyków; jedną z nich kładziemy:

Cóż to za rzesza ta / Prawidła za nic ma! / Prawidła święta rzecz / Romantyku nie przecz / Romantyk to jest gęś / La Harpie ${ }^{3}$ głową wstrzęś! / Czyż ćmić będzie twój rym / Gęsty ich szał jak dym. / Miotły! Miotełki! itd. (KP 1830, nr 160: 812).

Nawet, gdy wyrażano się krytycznie wobec hegemonii Chłopa Milionowego na scenie Teatru Narodowego, czyniono to czasem w formie śpiewki:

Jeden z miłośników sceny narodowego teatru, przybywszy z prowincji, gdy samego tylko Chłopa dawano odjechał oburzony na dyrekcją, a do Kurjera Polskiego posłał wiersz następujący w duchu kupletu miotlarza:

Jakiż to nowy cud, / Stolicy zwabia lud! / Cóż to za wrzawa, krzyk / Ten karet długi szyk! / Cóż to znaczy ten tłok, / Tych pieszych szybki krok! / Co biegnąc jakby w trop, / Wciąż mruczą: dzisiaj Chłop! / Miotły, miotełki! etc.

Oj wstyd Panowie wstyd! / Gdzie niegdyś świetniał Cyd, / Gdzie niegdyś świetniał rym, / Sławił Spartę lub Rzym, / Gdzie Cyrulika dźwięk, / Lub Desdemony jęk, / Tak mile dla nas brzmiał, / Dzisiaj Chłop wszystko zwiał. / Oj miotły, miotełki!

\footnotetext{
${ }^{3}$ Chodzi tu zapewne o Jean-François’a de La Harpe’a, francuskiego krytyka literackiego żyjącego na przełomie XVIII i XIX wieku (Truchet 1974: 1488 - 1492).
} 
Nie dla was górnych stref / W mej dłoni jest ten krzew, / Ten to młodości stróż, / Dla krzeseł i dla lóż, / Gdzie rozum idzie wspak, / A zły wkrada się smak, / Gdzie wzorów nie chca znać, / Jakież lekarstwo dać? / Miotły, miotełki! / Mam, i chętnie darmo dam (KP 1830 nr 31: 153).

Warto zwrócić zwłaszcza na klasistowską w wymowie ostatnią z przytoczonych piosenek. Może ona sugerować, że po pewnym czasie (powyższe piosenki opublikowano w prasie 3 stycznia 1830 , czyli niewiele ponad miesiąc po premierze Chłopa Milionowego w Warszawie), gdy elity znużyły się nieustanną obecnością melodramy Raimunda w Teatrze Narodowym, powstał wśród publiczności podział na dwie grupy. Jedna $\mathrm{z}$ nich zasiadała $\mathrm{w}$ prestiżowych lożach; była bogata i elitarna. Przypisywała sobie rolę arbitrów elegancji. Krytykowała drugą, która zadowalać się musiała gorszym i mniej wygodnym widokiem z parteru sali. Była ona uboższa i mniej prestiżowa. Cechowała się prostszym gustem. Opozycja ta nie zaszkodziła sztuce, która jeszcze przez wiele miesięcy bawiła warszawską publiczność. Czyni to z Chłopa Milionowego, a zwłaszcza „Miotełek”, swego rodzaju adoptowane dziecko plebejskiej kultury ludowej Warszawy.

Wszystkie powyżej przytoczone przykłady ukazują, jak nośną i chwytliwą była nie tylko treść „Miotełek”, ale i sama ich forma, która nie tylko mocno osadziła się w głowach wielu odbiorców, ale też dzięki prostej konstrukcji umożliwiała łatwe tworzenie własnych wariantów śpiewek. Piosenki Miotlarza były tak powszechnie znane i lubiane, że nawet osoby piszące o niezależnych od nich zjawiskach używały ich formy do wyrażenia swoich myśli.

\section{Treści „Miotelek”}

W tym miejscu chciałbym skupić się na „kanonicznych Miotełkach”, tj. tych, które były wykonywane na scenie Teatru Narodowego, tudzież wyszły spod pióra Nowakowskiego i zostały wydane jako osobne druki. Pomijam tu twórczość miłośników śpiewek, która w znacznej mierze kopiowała wzorce od Nowakowskiego i prawdopodobnie nie oddziaływała w społeczeństwie tak silnie jak jej pierwowzory. Wyjątki od tej reguły zostały już przedstawione powyżej. Ze względu na ich treść oraz tematykę „Miotełki” można podzielić na dwie grupy: „Miotełki” społeczne oraz „Miotełki” okolicznościowe.

\section{1. „Miotełki” społeczne}

Zdecydowana większość przetrwałych do dziś „Miotełek”, w tym te zawarte w drukowanym wydaniu Chtopa Milionowego, porusza tematyke obyczajowa i stanowi odbicie stosunków społecznych. Śpiewki te są wesołą i żartobliwą satyrą na ludzkie wady; wiele $\mathrm{z}$ nich posiada też wyraźny wydźwięk umoralniający. Zagadnienia pojawiające się w tego typu „Miotełkach” Nowakowskiego są różnorodne: brak szacunku i restrykcyjność możnych wobec biedniejszych i słabszych, pycha i wyniosłość osób z niższych klas, które próbują wznieść się ponad swój status (Raimund 1829: 97), dwulicowość i plotkarstwo (KW 1830, nr 7: 26), pogarda wobec ubogich i niemoralna pogoń za bogactwami, rozrzutność i hulaszczość (KW 1830, nr 23: 106), wywyższanie się i ignorancja (MT: MTIII97'3), niezachowywanie się stosownie do swoich lat (MT: MTIII97'9), wybredność panien na wydaniu wobec kandydatów o rękę (KP 1830, nr 86: 440), niezgoda w życiu małżeńskim oraz nieuprzejmość kawalerów wobec panien (KW 1830, nr 311: 1625). Wśród nich można jednak znaleźć też bardziej optymistyczne teksty, chociażby pochwalające osoby cnotliwe, które swoim codziennym życiem przyczyniają się do pomnażania dobra 
i rugowania zła (Raimund 1829: 97; KW 1830, nr 299: 1566). W „Miotełkach” autorstwa Niwińskiego, oprócz kontynuacji niektórych ww. wątków, pojawiają się kolejne postawy: zapatrzenie we wzorce zachodnie połączone $\mathrm{z}$ pogardą dla rzeczy rodzimych, krytykanctwo (KW 1830, nr 299: 1566) czy też pasożytnicze lichwiarstwo (KW 1830, nr 293: 1530).

Spektrum poruszanych zagadnień jest więc dość szerokie i umożliwia wgląd w to, jakie problemy były doświadczeniem wielu ówczesnych warszawiaków. Zarazem zdaje się ukazywać $\mathrm{w}$ ten sposób popularna aksjologia tamtych czasów, np. poszanowanie dla zgodnego życia małżeńskiego i instytucji rodziny (MT: MTIII97'6; KW 1830, nr 311: 1625) czy też głęboki szacunek i zrozumienie dla podziałów społecznych oraz pochwała akceptacji swojego stanu bytowania - ruchliwość społeczna, tak charakterystyczna dla XIX wieku, jest krytykowana sama w sobie (Raimund 1829: 97; MT: MTIII97'5; KW 1830, nr 247: 1296-1297). Nie zmienia to jednak faktu, że w „Miotełkach” widoczne są napięcia klasowe, przejawiające się w krytykowaniu postaw elit z perspektywy warstw niższych (Raimund 1829: 97_-97; MT: MTIII97'5; KW 1830, nr 23: 106). Z drugiej jednak strony „Miotełki” dotyczące zawierania związku małżeńskiego przedstawiają raczej zachowania mające miejsce wśród klas wyższych i to do nich kierują pouczenie. W ten sposób ukazuje się duża różnorodność tych piosenek - nie każda z nich musiała być adekwatna dla wszystkich słuchaczy, ale spośród istniejących utworów każdy mógł wybrać coś dla siebie.

Chcąc umiejscowić "Miotełki” społeczne na mapie dziewiętnastowiecznej literatury, warto spojrzeć wpierw na ich źródło ich pochodzenia. Chłop Milionowy Raimunda jest klasyfikowany jako dramat wyraźnie wpisujący się w nurt ideowy biedermeieru (Krzysztoforska-Weisswasser 2007: 176). Zawarte w tekście melodramy śpiewki Miotlarza także się weń wpasowują. Nadały one w znacznej mierze ton dalszej twórczości aktorów i miłośników. Występująca w „Miotełkach” afirmacja wartości takich, jak poszanowanie podziałów społecznych, umiarkowanie czy uznanie dla instytucji rodziny oraz życia prywatnego stanowią cechy charakterystyczne biedermeieru. Także typowa dla nich zwięzła forma, zwrócenie uwagi na życie mieszkańców miasta oraz umoralniająca humorystyczna treść przemawiają za taką klasyfikacją (Krzysztoforska-Weisswasser 166-172). Dzięki temu „Miotełki” być może stanowią najpopularniejszy na ziemiach polskich przykład recepcji tego wywodzącego się z Austrii nurtu.

\section{2. „Miotełki” okolicznościowe}

Jak już zostało wspomniane, forma literacka „Miotełki” stanowiła narzędzie, którym łatwo było się posłużyć w celu wyrażenia swoich pomysłów. Stąd też nie tylko wśród ich miłośników, ale też i na scenie, zdarzało się, że zwyczajowa tematyka „Miotełki” ustępowała innej.

W formie „Miotełki” wyrazy uznania i wdzięczności wobec publiki teatralnej składali zarówno Nowakowski (KW 1829, nr 334: 1503), jak i Niwiński (KW 1830, nr 293: 1530). Ze sceny składano również życzenia noworoczne (PDK 1830, $\mathrm{nr} 2: 10$ ).

Szczególnym rodzajem okolicznościowych śpiewek były teksty, które wykonane zostały w Teatrze Narodowym kilkanaście dni po wybuchu powstania listopadowego. Wyrażały one nastroje patriotyczne, tęsknotę za wolnościa od carskiego zwierzchnictwa oraz dezaprobatę wobec tchórzostwa czy współpracy z Rosją (KW 1830, nr 331: 1721). Doszło przez to do transgresji gatunku „Miotełki” - lekka, niewyrafinowana forma literacka, która dotychczas służyła żartobliwemu komentowaniu codziennych zjawisk, została wprzęgnięta w służbę wielkich narodowych idei. Bedermeierowską przytulność 
i ład porzucono na rzecz romantycznego uniesienia. Niwiński poruszał już wcześniej na deskach teatru zagadnienia patriotyczne, jednakże do tej pory czynił to przy zachowaniu żartobliwego, nieco ironicznego tonu piosenek (KW 1830, nr 299: 1566). Po wybuchu powstania sytuacja zmieniła się: przy zachowaniu ogólnej formy literackiej „Miotełek” ich treść stała się poważna. Może to stanowić przesłankę do wnioskowania, że po roku od premiery Chłopa Milionowego śpiewki Miotlarza tak bardzo zakorzeniły się w świadomości warszawiaków, że czymś naturalnym dla Niwińskiego było użycie ich do ekspresji nastrojów patriotycznych. Piosenek o tej tematyce zachowały się do dziś tylko trzy. Niestety w sferze czystej spekulacji pozostaje kwestia, czy powstało ich więcej i jaką szerszą recepcję miały one w społeczeństwie.

$\mathrm{Na}$ powstańczych tekstach Niwińskiego, wykonanych na deskach Teatru Narodowego 8 XII 1830 r., kończy się uchwytna dzięki źródłom historia społecznokulturowego fenomenu, jakim były „Miotełki”.

\section{Wnioski}

Zjawisko pojawienia się i błyskawicznej szerokiej popularyzacja „Miotełek” było niezwykłe w swoich czasach. Trafiały one do szerokich kręgów społecznych młodszych i starszych, elit i biednych, Polaków i Żydów. Jakie czynniki mogły wpłynąć na pojawienie się i rozwój tego fenomenu?

Trafna zdaje się odpowiedź, jaką proponowali już żyjący wówczas. Przyjemna dla ucha, chwytliwa melodia oraz nieskomplikowane, rytmiczne teksty, traktujące w przystępny sposób o powszechnie znanych zagadnieniach stanowiły te czynniki, którym śpiewki zawdzięczały swoją popularność (KP 1829, nr 29: 146). Można było znaleźć upodobanie w miłej warstwie dźwiękowej, która zaintrygowała zarówno Żydów z ulicy Franciszkańskiej, jak i Fryderyka Chopina, a także utożsamić się ze słowami, które przedstawiały tak pospolite zjawiska, że odnaleźć się mógł w nich niemal każdy.

To upowszechnianie zdaje się zresztą być mechanizmem w pewnej mierze niezależnym od miejsca i czasu. Viral videos, chwytliwe piosenki z radia czy też popularne internetowe memy - to wszystko wydaje się niczym więcej, jak po prostu „Miotełkami” na miarę mediów masowych XXI wieku; albo też odwrotnie - to „Miotełki” ze swoim sukcesem wśród szerokich mas były przebojem na miarę Warszawy przełomu lat 20. i 30. XIX wieku. Kiedy przyglądamy się badaniom prowadzonym nad zjawiskami zachodzącymi w Internecie zwraca uwage fakt, że mechanizmy popularności są we wszystkich tych czasach podobne: mamy tu do czynienia z sytuacją, gdy prosty, łatwy do zapamiętania utwór, trafia w gusta publiki a jego popularność błyskawicznie zatacza coraz szersze kręgi (Burgess 2008: 101109). Graficzno-tekstowa forma wydawania „Miotełek” jako osobnych druków, gdzie barwnej litografii towarzyszy zwięzły i błyskotliwy tekst, jeszcze mocniej przywołuje skojarzenie $\mathrm{Z}$ internetowymi memami. Za tym skojarzeniem przemawia również oczywiście wielka popularność piosenek oraz ich podatność na modyfikowanie przez odbiorców, gdzie twory pierwotne i wtórne mogły funkcjonować na równych niemal prawach w oderwaniu od swoich autorów tudzież pierwotnych wykonawców (Burgess 2008: 101-102)

Dzięki przełamywaniu tradycyjnych podziałów na niskie i wysokie, historia „Miotełek” podobna jest do zjawisk kultury masowej. Gdyby pójść za niektórymi tradycyjnymi pomysłami, wyznaczającymi początki kultury masowej w czasach intensywnej industrializacji i ściśle wiążącymi je z masowymi środkami przekazu (Kłoskowska 2006: 94), „Miotełki”, choć nie poddawałyby w wątpliwość całej tej koncepcji, to mogłyby jednak stanowić pewną interesującą zapowiedź późniejszych 
zdarzeń albo wręcz ciekawy, choć relatywnie skromny jeśli chodzi o rozmiary, wyjątek od reguły. Jeśli jednak przystać na propozycje definiujące kulture popularną szerzej, jako fenomen sięgający zdecydowanie dawniejszych czasów (Lowenthal 2012: 49-54), „Miotełki” stają się jego pełnoprawnym przykładem. Ze współczesną skomercjalizowaną kulturą masową kojarzą się zaś spory o autorstwo toczone pomiędzy Nowakowskim a Damsem na łamach prasy.

Zachowania niektórych miłośników piosenek Miotlarza przypominają zaś fandom, czyli istniejące współcześnie grupy fanów, którzy gromadzą się wokół swoich ulubionych tekstów kultury (Kulesza-Gulczyńska 2014: 163-168). Najzagorzalszych entuzjastów „Miotełek” można określić ukutym przez Henrego Jenkinsa terminem kłusowników tekstów (textual poachers), czyli osób nie ograniczających się do biernego konsumowania kultury, a kreatywnie przetwarzających ją na swój sposób poprzez tworzenie własnych utworów (Jenkins 2005: 24-28). Zjawisko to, choć opisane przez Jenkinsa na podstawie przykładów z II połowy XX wieku, w swojej ogólnej formie sięgało korzeniami o wiele wcześniej, czego świadectwo stanowią chociażby „niekanoniczne” piosenki Miotlarza. To częściowe rozmycie się podziału na twórców i odbiorców stanowi istotne podobieństwo do kultury popularnej doby płynnej nowoczesności (Jenkins 2010: 109-110). Zarazem ów fakt mógłby być kluczowym argumentem dla uznania „Miotełek” za zjawisko kultury popularnej dla tych, którzy za istotną jej cechę uznają wykraczanie poza ramy „oficjalnego” obiegu oraz powiązań komercyjnych (Fieske 1995: 2) - wszak choć śpiewki Miotlarza były tworzone w celach zarobkowych, ich popularność wykraczała poza samo nabywanie i wykonywanie ich tekstów. Zaś pojawienie się osób przebranych za Miotlarzy na zabawach karnawałowych przypomina współczesne zjawisko cosplay’u, czyli stylizowania się na ulubioną postać literacką/filmową przy okazji spotkań z innymi miłośnikami danego dzieła. W obydwu tych przypadkach mamy do czynienia z zachowaniem, które stanowi przykład publicznego demonstrowania wśród innych entuzjastów fascynacji jakimś popularnym utworem (Lamerichs 2014: 114) - jednakże przy warszawskich zabawach karnawałowych 1830 roku raczej zlecano komuś przebranie się niż czyniono to osobiście.

Przy wszystkich wyżej zarysowanych analogiach należy wszak zachować stosowną ostrożność, by nie popaść w przesadę. Przede wszystkim „Miotełkom” brakowało trwałych i skoordynowanych grup zwolenników, które są istotnym wyznacznikiem fandomu. Trudno tu mówić o pełnoprawnych fanklubach (Jenkins 2005: 77-78). Poza tym niemożliwa do określenia pozostaje dokładna skala popularności „Miotełek” w Warszawie, choć wiemy, że zawędrowały one do Lublina czy też na prowincję. Co prawda prasa pisała o tym, że te popularne piosenki ,powtarza każdy i każda, jeśli nie słowa, to przynajmniej ich melodię” (KP 1829, nr 29: 146), lecz nie sposób określić, jaki zakres osób rozumiano pod słowami „każdy i każda” (bo prawdopodobnie jednak nie wszystkich mieszkańców miasta).

Niemniej jednak nie jest nadużyciem stwierdzenie, że fenomen „Miotełek” był wydarzeniem $\mathrm{z}$ jednej strony wyjątkowym w swoich czasach, a z drugiej wiele o nich mówiącym. Piosenki Miotlarza oraz wydarzenia z nimi związane ukazują nam, jak bardzo podobne były do naszych czasów liczne aspekty wieku XIX, ale też jak bardzo owe czasy różniły się od tych, w których żyjemy. Śpiewki Miotlarza niewątpliwie stanowią istotną pozostałość po kulturze Warszawy pierwszej połowy XIX wieku. 


\section{Dodatek: wybór tekstów „Miotelek”}

„Co to za panicz tam, / Popędza konia sam, / A furman za pan brat, / Co za przewrotny świat, / Na panny rzuca wzrok, / Gdzie nędzarz patrzy w bok, / Hej! hej! Miotełki mam, / Dla pana tanio dam. / Miotły! Miotełki!" (Raimund 1829: 94)

„Cóż to za pani ta, / Co na łbie fiołki ma, / Krok szumny, śmiały gest, / Wszak to kucharka jest. / Nie pójdziesz ty mi stąd, / Do kuchni zaraz w kąt, / Dla takich wielkich dam, / Miotełki mokre mam. / Miotły! Miotełki!" (Raimund 1829: 97)

„A to ten wielki pan, / Z swej hardej duszy znan, / Dmie się jak gdyby paw, / Ani się w oczy staw. / Choć skarżyć chcesz to cyt, / Bo będziesz za to bit; / Wiec takiej dumnej głowie, / Człek w kącie tylko powie: / „Miotły Miotełki!” (Raimund 1829: 97)

„Lecz czasem ma i świat, / Wśród cierni piękny kwiat, / Nie sama na nim złość, / Jest i dobrego dość. / Są co wspierają je, / Co śmiało ganią złe, / Dla takich respekt znam, / Lecz dla złych... miotły mam. / Miotły! Miotełki!” (Raimund 1829: 97-98)

„Ów tylko w złoto dmie, / Uboższych śmieciem zwie, / A wiem że brudny zysk / Zaśniedził złota błysk. / Ej cicho siedź, bo kmieć, / Wygarnie z kątów śmieć, / Ty coś pomiatać chciał / Dopiero będziesz znał / Co Miotły Miotełki” (KW 1830, nr 23: 106).

„Oj bieda z Panią tą, / Gardziła męską płcią, / Choć który trafiał się / To ona - nie i nie. - / A dziś gdy grubszy głos, / Twarz chudsza, dłuższy nos, / Mniej sroga może już / Lecz chłopcy - ani rusz. / Miotły! Miotełki!” (KP 1830, nr 86: 440)

„Jak piękny hoży człek! / Młodości kwitnie wiek! / Szkoda że taki fryc, / Nie czytał widzę nic! / Że umie ABC / Więc mędrkiem już być chce / Mam ja Miotełki mam, / A panu - także dam / Miotty! Miotełki!" (KW 1830, nr 81: 405)

„Oj to paniątko dmie, / Wziął w spadku cztery wsie, / Więc szampan, burgund, sztos, / Wżyjmy co dał los!... / Lecz wkrótce będzie wstyd / Gdy z wekslem przyjdzie Żyd, / A miotlarz stojąc tu / Zaśpiewa z cicha mu / Miotły! Miotełki!” (KW 1830, nr 293: 1530)

„A tam kto, znowu kto? / Popędza czwórką w cwał, / To lichwiarz, sto za sto / W procencie tylko brał. / Wygląda sam jak lew / Bo z innych wyssał krew, / Dla niego zawsze mam / I bez procentu dam... / Miotty! Miotełki!" (KW 1830, nr 293: 1530)

„Czy jawa, czy to sen? / Nie... Prawda widok ten... / Wzleciał wolności ptak, / To szczęścia dla nas znak. / Walecznej młodzi krew, / Ojczysty zbawia krzew / Precz miotły.... Młodzi cześć / Tym z duszy spieszę nieść / Laury! Wawrzyny!" (KW 1830, nr 331: 1721)

\section{Bibliografia}

BURgess, J. (2008). „All Your Chocolate Rain Are Belong to Us?”Viral Video, YouTube and the Dynamics of Participatory Culture. W: G. Lovink (red.), Video Vortex Reader: Responses to YouTube (s. 101-109). Amsterdam: Institute of Network Cultures.

FIESKE, J. (1995). Reading the Popular. London-New York: Routledge.

„Gazeta Korrespondenta Warszawskiego y Zagranicznego" 1829, nr: 274 (27 XI), 280 (4 XII), 281 (5 XII), 299 (28 XII).

„Gazeta Polska” 1829, nr: 323 (2 XII), 327 (6 XII), 329 (9 XII), 330 (10 XII), 342 (22 XII), 348 (29 XII). 
Jenkins, H. (2005). Textual Poachers. Television Fans \& Participatory Culture. London-New York: Routledge.

Jenkins, H. (2010), What Happened Before YouTube. W: J. Burgess, J. Green (red.), YouTube. Online Video and Participatory Culture (s. 109-126). Cambridge-Malden: Polity Press.

KŁosKowsKA, A. (2006). Kultura Masowa. Krytyka i Obrona. Warszawa: Wydawnictwo Naukowe PWN.

KULESZA-GULCZYŃSKA, B. (2014). Znaczenie internetu $w$ rozwoju fan fiction, czyli twórczość fanowska i nowe media. W: J. Bierówka, K. Pokorna-Ignatowicz (red.), Media - kultura popularna - polityka. Wzajemne oddziatywania $i$ nowe zjawiska (s. 163-180). Kraków: Krakowska Akademia im. Andrzeja Frycza Modrzewskiego.

„Kurjer Polski” 1829, nr: 1 (1 XII), 5 (5 XII), 7 (7 XII), 21 (22 XII), 29 (31 XII).

„Kurjer Polski” 1830, nr: 31 (3 I), 79 (22 II), 86 (1 III), 121 (6 IV), 129 (15 IV), 140 (26 IV), $153(10 \mathrm{~V}), 160(17 \mathrm{~V})$.

„Kurjer Warszawski” 1829, nr: 293 (31 X), 319 (28 XI), 322 (1 XII), 327 (6 XII), 329 (9 XII), 334 (14 XII), 337 (17 XII), 341 (21 XII), 342 (22 XII), 343 (23 XII), 346 (27 XII).

„Kurjer Warszawski” 1830, nr: 7 (8 I), 23 (24 I), 24 (25 I), 50 (21 II), 66 (9 III), 247 (15 IX), 293 (31 X), 299 (7 XI), 311 (19 XI), 331 (10 XII).

KRZYSZTOFORSKA-WEISSWASSER, Z. (2007). Austriacki biedermeier i jego sztuka. W: G. Borkowska, A. Mazru (red.), Codzienność w literaturze XIX (i XX) wieku. Od Adalberta Stiftera do wspótczesności (s. 165-184). Opole: Wydawnictwo Uniwersytetu Opolskiego.

LAMERICHS, N. (2014). Consuming as Subculture: The Multiple Bodies in Cosplay. "Scene", 2 (1-2), 113-125.

Lowenthal, L. (2012). Historical perspectives of popular culture. W: Ch. Rojek (red.),

Popular Culture. Critical Concepts in Media and Cultural Studies (s. 49-64). London-New York: Routledge.

MiziołeK, J. (2015). Teatr Wielki w Warszawie. 250-lecie Teatru Publicznego w Polsce 1765-2015. Warszawa: Teatr Wielki - Opera Narodowa.

Muzeum Teatralne W Warszawie, syg. MTIII97'1 - MTIII97'13.

„Powszechny Dziennik Krajowy” 1829, nr: 308 (29 XI), 317 (8 XII), 330 (21 XII), 334 (26 XII), 337 (29 XII).

„Powszechny Dziennik Krajowy” 1830, nr 2 (3 I).

RAIMUND, F. (1829). Chłop milionowy, czyli Dziewczyna z świata czarownego. Melodrama alegoryczna $w 3$ aktach $z$ niemieckiego p. Raimund przerobiona przez Józefa Damse artystę dramatycznego Teatru Narodowego z muzyka p. Drechsler (przeł. J. Damse). Warszawa: Drukiem A. Gałęzowskiego i Komp.

RASZEWSKI, Z. i in (1973). Stownik Biograficzny Teatru Polskiego 1765-1965. Warszawa: Państwowe Wydawnictwo Naukowe.

SzWANKOWSKI, E. (1973). Repertuar Teatrów Warszawskich 1814-1831. Warszawa: Instytut Sztuki Polskiej Akademii Nauk.

TruChET, J. (1974). Théâtre du XVIIIe siècle (Vol. 2). Paris: Gallimard.

WaszKIEL, H, (2015), Trudne lata. Teatr Warszawski 1815-1868. Warszawa: Teatr Narodowy. 


\section{LUKASZ KOŻUCHOWSKI}

"The Little Brooms" from the Melodrama The Peasant as a Millionaire as Warsaw Sociocultural Phenomenon

The main goal of the article is to shed some light on the social phenomenon known as "Miotełki" ("The Little Brooms"), which gained popularity in the 20's and 30 's of the 19th-century Warsaw. "Miotełki" was a term used to address songs originating from Chłop Milionowy (The Peasant as a Millionaire), an extraordinarily popular contemporary melodrama. The first performer of these songs was Jan Nowakowski, a well-liked actor of the National Theatre in Warsaw. The article shows the rising popularity of "Miotełki" and concentrates on their role as a sociocultural phenomenon. The songs managed to transcend social class barriers - from mentions in magazines and well-educated conversations to serving as simple people's catchy tunes. The fame of "Miotełki"'s lasted until the November Insurrection, during which they evolved from representing the everyday life slightly ironically and in an entertaining way to serving as a tool of patriotic propaganda. That very fact is considered to be what we would call today an example of fan culture. The article also focuses on the themes that appeared in in the songs, such as a deep respect for family or the affirmation of social divisions, all of which contributed to their success as being important to the inhabitants of Warsaw. 